УДК: 81'276.6:62

DOI: $10.22363 / 2313-2299-2019-10-1-187-196$

\title{
EFFECTIVENESS VS. EFFICIENCY: AN ANALYSIS OF VALENCY AND COLLOCABILITY IN A TECHNICAL CONTEXT
}

\author{
Yulia A. Filyasova \\ Saint-Petersburg Mining University \\ $21^{\text {st }}$ Line, 2, Vasilievsky Island, St. Petersburg, Russia, 199106
}

\begin{abstract}
Abatract. The article presents the results of a lexico-syntactic analysis of valency and collocability of English words, related to one semantic group: effectiveness and efficiency. The aim of the research was to study the ability of these words to syntactically and lexically contact with other words, taking into consideration certain difference between their lexical meanings. The objectives included determining semantic variations and analysis of word classes in the left and right contexts. The material, 177,144 words, comprised 700 article titles and abstracts from seven international journals with geological and petroleumrelated specializations. Methods of study involved continuous sampling, classification, and analysis of lexical meanings of relevant words. It was found that the frequency of effectiveness was $40 \%$ higher than that of efficiency. Both of them had similarities in syntactic valency: they occurred in identical syntactic structures, however, with different rates of occurrence. The difference is the most obvious in such syntactic structures as $\mathrm{N}(\mathrm{E})+\mathrm{of}+\mathrm{N}$ - characteristic of effectiveness, and $\mathrm{V}+\mathrm{A}+\mathrm{N}(\mathrm{E})$ - specific to efficiency. A typical example of effectiveness was the effectiveness of the proposed method, while that of efficiency - improve production efficiency. Effectiveness collocated more often with method-related notions, whereas efficiency - with processes. The gained data correlate with the definitions: effectiveness has a wider semantic field (which explains a higher rate of its occurrence) and is oriented towards result, while efficiency implies process and has an additional technical meaning. The data can be used in the practice of teaching English as a second language for students with technical specializations and technical translation.
\end{abstract}

Key words: valency, collocability, word frequency, syntactic structure, the English language

\section{INTRODUCTION}

Lexical valency is defined as the aptness of a word to appear in various combinations. The range of the lexical valency of words is linguistically restricted by the inner structure of the English word-stock. This can be easily observed in the selection of synonyms found in different word-groups. Though the verbs lift and raise are usually treated as synonyms, it is only the latter that is collocated with the noun question. The verb take may be synonymically interpreted as grasp, seize, catch, lay hold of, etc., but it is only take that is found in collocation with the nouns examination, measures, precautions, etc.; only catch in catch smb. napping and grasp in grasp the truth [1. p. 6465]. Lexical collocability is understood as the ability of a lexeme to collocate with a class of lexemes (allolexes) on the basis of the common classeme, which is a case of semantic accord. The class of lexemes forms the domain of the use of the lexeme delimited by the explanation of its sememe. This explanation represents the semantic norm of the lexeme [2. p. 176]. The terms collocability and valency are considered to be 
distinct in the following manner: the former is defined as a particular actualization of a lexical unit's ability to collocate with other lexical units, leading to a conceptual combination; the latter is opposed as potential ability of lexical units to collocate with other units of the same category [3. p. 75]. Valency is also understood as the ability of lexical units to interact with other units at close and distant relations, or in micro and macro contexts. Valency is related to such notions as 'position' and 'function'. According to S.D. Katznelson, in such languages as English valency and collocability are purely distinct [4. p. 20].

For speech production, lexical meaning has a more important function, in contrast to grammatical meaning, for identification of potential collocations, syntactic structures and their components. In other words, lexical meaning sets those main parameters of a sentence-utterance, which pre-determine extra-linguistic reality [5. p. 41]. Despite the fact that lexical system is difficult to study in contrast with phonetic and grammatical systems, as it is based on hundreds of thousands of units, exposed to social and other influences, and therefore, vulnerable to dramatic and seemingly non-systemic changes [6. p. 23], research into lexical valency is relevant nowadays, as it opens new horizons in understanding implicit connections of nominations, collocability, interactions of linguistic structures, and communication [7. p. 112-114].

Each speaker of a human language knows that words in sentences are organized into classes of hierarchically-defined phrases, each with distinctive clusters of properties pertaining to internal structure and external distribution [8. p. 2]. The most obvious formal property of utterances is their bracketing into constituents of various types that is 'the tree structure' associated with them [9. p. 12] (Fig. 1). Within a sentence, the following types of phrase can be distinguished: nominal, verbal, adjectival, adverbial, and statival phrases [10. p. 319].

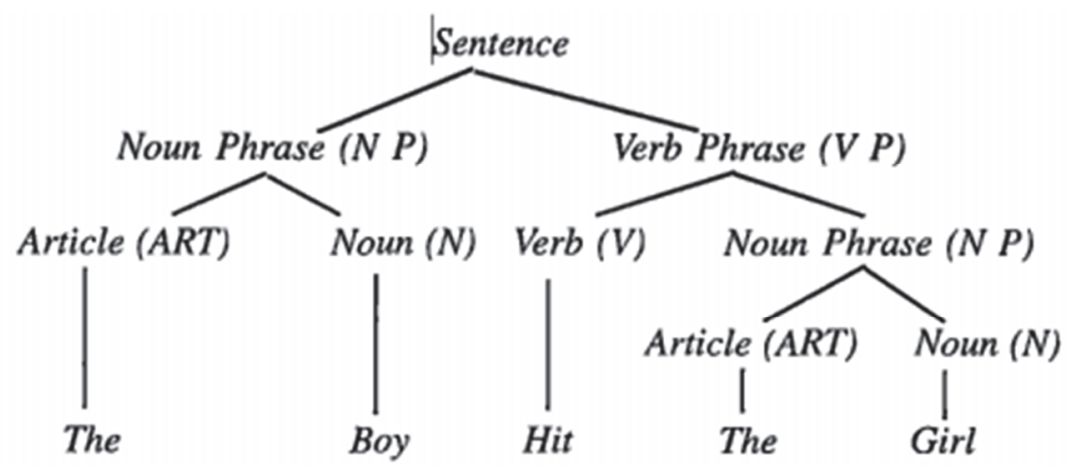

Fig. 1. Structural representation of a sentence /

Рис. 1. Структурная репрезентация предложения

Semantics and grammar are closely related areas: "the semantic component determines the semantic interpretation of a sentence. That is, it relates a structure generated by the syntactic component to a certain semantic representation" [9. p. 16]. Similarly, lexical and grammatical types of valency are closely interconnected [11. p. 78]. Syntactic valency of a word ' $\mathrm{A}$ ' is a system of potential positions which other words can take, when 'A' occurs in speech. Lexical valency is a particular set of words which occur 
in speech together with 'A'. Valency of a word depends on its lexical class, on the one hand, and its lexical meaning, on the other hand. Semantics of a word determines its valency properties. It is important to note that the semantic spectrum of a word, which appears in a context, is often different from that in dictionaries [12. p. 39]. Context is a mechanism and a result of actualization of syntagmatic properties, characteristic of lexical units. Such properties are determined and regulated by collocation norms of words in a text [13. p. 50].

Semantic groups can be divided into two types: 1) contextual, in which words collocate because the phenomena they denote are frequently used in one context, for example, sun, shine and brightly; and 2) logical, in which words are grouped because they denote generic terms, e.g. shine, light, blaze, flare, flash, gleam, glimmer, glint, glow, shimmer, spark, sparkle, twinkle [14. p. 93].

The words effectiveness (EFS) and efficiency (EFC) are interrelated and constitute one logical semantic group as they have similar components of meaning, for examples, work well and produce good results. However, contextually they are not always replaceable. This study is aimed at understanding syntactic valency and lexical collocability of these lexical units through their contextual illustration on the material of technical research article titles and abstracts on petroleum science. Practically, the results could be of interest for specialists in technical translation and teaching technical English as a second language (L2) [15]. Learners of a foreign language never make semantic mistakes since logical principles, determining the structure of actual denotation, are common for all languages; however, they might not know the rules of lexical collocability [16. p. 120].

\section{MATERIAL}

700 headlines and abstracts from seven journals: Journal of Petroleum Geology [17], Petroleum Geoscience [18], Journal of Unconventional Oil and Gas Resources [19], Journal of Petroleum Science and Engineering [20], Marine and Petroleum Geology [21], Petroleum Exploration and Development [22], Petroleum Science [23] — were equally selected (100 from each) over the recent five years 2013-2018 and analyzed for the valency and collocability of the words EFS and EFC in the technical context. The volume of the original material was $1,210,427$ characters, or 177,444 words. The rates of occurrence were 150 for EFS and 89 for EFC.

The analysis of dictionary definitions revealed common and distinctive features in the semantics of these words:

- Common - 1) working well; 2) producing good results [24].

- Distinctive - effective: a. successful; b. if changes, laws, etc become effective, they officially start; c. used to say what the real situation is although officially it is different [25]; d. producing a decided, decisive, or desired effect; e. impressive, striking; f. actual; g. ready for service or action [26].

Efficient: using the available time, money, supplies, and energy.

Efficiency: the ratio of the useful energy delivered by a dynamic system to the energy supplied to it [26]; (technical) the ratio of the useful work performed by a machine or in a process to the total energy expended or heat taken in [27].

Generally, EFS has a wider semantic field and is oriented towards result, while $\mathrm{EFC}$ is more of a process-oriented word, with a technical meaning. 


\section{METHODS}

Collocations of EFS and EFC were counted and compared in the left and right contexts. A contextual study made it possible to distinguish the following generalized syntactic phrase structures, typical of both EFS and EFC, for their further lexical analysis, where (E) stands for Effectiveness/Efficiency:

1. Verbal structure: $\mathrm{V}+\mathrm{N}(\mathrm{E})+\mathrm{of}+\mathrm{N}$.

2. Nominal structure: $\mathrm{N}(\mathrm{E})+\mathrm{of}+\mathrm{N}$.

3. Verbal structure: $V+A+N(E)$.

4. Nominal structure: $A+N(E)$.

5. Adjectival structure: $\mathrm{A}(\mathrm{E})+\mathrm{N}$.

6. Miscellaneous.

\section{RESULTS}

1. Verbal structure: $\mathbf{V}+\mathbf{N}(\mathbf{E})+\mathbf{o f}+\mathbf{N}$. For the first structure, there were 48 contextual realizations of EFS (Tb. 1). Verbs in the left context included: assess (7), change, compare, control, demonstrate (2), diminish, discuss, enhance, establish, evaluate (7), gauge, illustrate (2), improve (4), indicate, investigate (2), manipulate, re-evaluate, quantify (2), show (3), study, test, validate, verify (5).

Table 1 / Таблица 1

Syntactic structure / Синтаксическая структура: $\mathbf{V}$ (verb) + Article $+\mathbf{N}(E)+\mathbf{P}$ (preposition) $+\mathbf{A}$ (adjective) $/$ Article $+\mathbf{N}$ (noun)

\begin{tabular}{|l|l|l|}
\hline \multicolumn{1}{|c|}{$\mathrm{V}$} & Art. $+\mathrm{EFS}(\mathrm{P})$ & \multicolumn{1}{c|}{$\mathrm{A} /$ Art. $+\mathrm{N}$} \\
\hline re-evaluate & the EFS of & chemical blends \\
\hline illustrate & the EFS of & the method \\
\hline quantify & the EFS of & degradable fibers \\
\hline evaluate & the EFS of & different viscosity reducers \\
\hline \multicolumn{1}{|c|}{$\mathrm{V}$} & Art. $+\mathrm{EFC}+\mathrm{P}$ & \multicolumn{1}{c|}{$\mathrm{A}+\mathrm{N}$} \\
\hline improve & the EFC of & mining \\
\hline determine & the EFC of & volcanic reservoirs \\
\hline increase & the EFC of & calcium sulfate scale prevention \\
\hline compare & the EFC of & combustion and pyrolysis \\
\hline
\end{tabular}

As for EFC, there were only 19 cases of occurrence, only $40 \%$ of those of EFS (Tb. 1). The verbs in the left context were the following: analyze, compare, control, determine, enhance (3), evaluate (2), improve (7), increase, investigate, quantify.

Six verbs were identical for EFS and EFC: compare, control, enhance, evaluate, improve, and quantify. Taking into consideration repeated use of some of the verbs, 16 of them were identical, which means that $33 \%(16 / 48)$ of coincidence for EFS, and $79 \%(15 / 19)$ - for EFC. Hence, the collocability of EFS with verbs was wider.

EFS's right context included method-related concepts (14): geostatistical methods; industrial activities (12): CO2-enhanced oil shale recovery; systemic notions (7): the operator training system; objects of industrial activity (6): highly-conductive zone; substances (4): additives; time-space characteristics (4): horizontal interval; industrial processes (1): acidizing. That of EFC — industrial activities (7): mining; industrial processes (6): the fracturing process; systemic notions (2): Venezuela's economic system; objects of industrial activity (2): the multi-strategy classifier; time-space characteristics (1): 
volcanic reservoirs; substances (1): various drag reducing agents. Collocations with EFS comprised method-related concepts, which were not typical of EFC. EFS's left verbal context (assess, evaluate, verify) also matched the semantics of method.

2. Nominal structure: $\mathbf{N}(\mathbf{E})+\mathbf{o f}+\mathbf{N}$. The overwhelming majority of realizations, 50, belonged to EFS; while only six - to EFC: the efficiency of play; carbonate based solutions; natural gas-fired electricity; the inhibitor; enhanced oil recovery; this technique. The presence of EFC in this syntactic structure testifies that this word can take this position, but not very commonly. The right context for EFS included methods (21): the proposed technique, the proposed approach; industrial processes and activities (13): gas generation; industrial objects (8): secondary play; substances (8): the surfactant.

3. Verbal structure: $\mathbf{V}+\mathbf{A}+\mathbf{N}(\mathbf{E})$. Its difference from structure (1) is that it exposes the nouns' opportunities to collocate with other nominals in the left context, following the verb (Tb. 2). 11 realizations of this structure were observed for EFS and 33 - for EFC, six phrases with the post-position in the right context among them. 27 verbs in the left context included: affect, double, enhance, have impact on, identify, improve (12), increase (2), influence (2), maintain, recover, result in (3), suffer from. Comparing them to those, relating to EFS, only one verb was identical: improve: improve the development EFS of reservoir; improve gas recovery / the sweep / displacement / production / market EFC.

Table 2 / Таблица 2

Syntactic structure / Синтаксическая структура:

$\mathbf{V}($ verb) + Art. (article) $+\mathbf{A}$ (adjective) $+\mathbf{N} €+\mathbf{P}($ preposition $)+\mathbf{A}+\mathrm{N}$

\begin{tabular}{|c|l|l|l|}
\hline \multicolumn{1}{|c|}{$($ Art. $)+A$} & EFS $(+P)$ & \\
\hline evaluate & the job & EFS & \\
\hline evaluate & fracture & EFS & \\
\hline evaluate & weathered crust reservoir & EFS & \\
\hline improve & the development & EFS of & reservoir \\
\hline $\mathrm{V}$ & \multicolumn{1}{|c|}{$($ Art. $)+\mathrm{A}$} & EFC $(+\mathrm{P})$ & \\
\hline double & proppant placement & EFC & \\
\hline result in & poor sweep & EFC & A+N \\
\hline improve & the development & EFC of & heavy oil, shale oil and other resources \\
\hline improve & the inversion & EFC of & highly deviated and horizontal wells logging data \\
\hline increase & the inhibition & EFC of & calcium sulfate scale formation in oil reservoirs \\
\hline estimate & the displacement & EFC of & water displacing oil \\
\hline
\end{tabular}

EFS included nine attributes in the left context: methods (6), industrial activities and processes (4), production-related indicators (2), and an adjective, e.g. development, applications, fracture, expected. EFC was preceded by industrial activities and processes (19, or $57 \%$ ), ratio (12, or $37 \%$ ), economy-related terms (2), e.g. recovery, production, inversion, inhibition, market, sweep.

4. Nominal structure: $\mathbf{A}+\mathbf{N}(\mathbf{E})$. This structure leaves out the verb in the initial position (cf. 3). It was represented by 32 realizations of EFS, and 22 those of EFC. EFS was preceded by lexical units denoting objects of industrial activities and processes (27, or $84 \%)$, substances $(2$, or $6 \%$ ), adjectives $(2$, or $6 \%)$, equipment (3\%), e.g. diversion, exploration, production, stimulation, reduction, stimulation, reservoir, source, foam, fracture, compounds, three chemical fluid compositions, acid, regional-distinct, pump; EFC — by nouns, denoting industrial activities and processes (15, or $70 \%)$, and 
5 (or 30\%) nouns, related to the meaning of ratio, e.g. displacement, production, recovery, sealing, energy transfer, expulsion, inhibition, injection, brake thermal, catalytic, $W A G$ (water-alternating gas), sweep. The percentage of the constituent groups demonstrates the presence of process-related nouns in the left context of both EFS and EFC; however, the majority characterizes EFC.

5. Adjectival structure: $\mathbf{A}(\mathbf{E})+\mathbf{N}$. This group included three examples for EFS: well-log EFS estimation, acid EFS evaluation and sealing EFS ratio; and two realizations of EFC: wormhole EFC relationships and EFC development technique. Arguably, the adjectival position is not typical either of EFS or EFC.

6. Miscellaneous. The structure $\mathrm{A}+\mathrm{N}(\mathrm{E})+\mathrm{of}+\mathrm{N}$ was observed twice for EFC: the system EFC of single well and the maximum conversion EFC of fatty acids, in which EFC had the technical meaning of ratio. EFS had two realizations, related to methods in the right context: the recovery EFS of the two production methods and the development EFS of SAGD (steam-assisted gravity drainage). Structures, rarely occurring in the technical context, also included $\mathrm{N}+\mathrm{P}+\mathrm{N}(\mathrm{E})+\mathrm{P}+\mathrm{N}$ : evaluation of the EFS of chemical flooding, the reduction of the EFS of these processes, impact on the EFC of enhanced oil recovery; and $\mathrm{N}+\mathrm{of}+\mathrm{N}(\mathrm{E})$ : a good indicator of the EFS, three tiers of EFS, the comparison of the EFC. Occasional examples were the effects of $\mathrm{CO}_{2}$ molecular diffusion, nanopore confinement, and stress-dependent deformation on $\mathrm{CO}_{2}-E O R$ EFS; the effects of addition of sodium hydroxide to the solution on the gas sweetening performance and $E F C$; among others.

Table 3 / Таблица 3

Consolidated data on syntactic valency /

Сводные данные о синтаксической валентности

\begin{tabular}{|l|c|c|}
\hline \multicolumn{1}{|c|}{ Syntactic structures } & Effectiveness & Efficiency \\
\hline 1. Verbal structure: $\mathrm{V}+\mathrm{N}(\mathrm{E})+\mathrm{Of}+\mathrm{N}$ & $32 \%$ & $21 \%$ \\
\hline 2. Nominal structure: $\mathrm{N}(\mathrm{E})+\mathrm{Of}+\mathrm{N}$ & $33 \%$ & $7 \%$ \\
\hline 3. Verbal structure: $\mathrm{V}+\mathrm{A}+\mathrm{N}(\mathrm{E})$ & $7 \%$ & $25 \%$ \\
\hline 4. Nominal structure: $\mathrm{A}+\mathrm{N}(\mathrm{E})$ & $21 \%$ & $2 \%$ \\
\hline 5. Adjectival structure: $\mathrm{A}(\mathrm{E})+\mathrm{N}$ & $2 \%$ & $7 \%$ \\
\hline 6. Miscellaneous & $5 \%$ & \\
\hline
\end{tabular}

\section{CONCLUSION}

To summarize, in this article, an attempt to analyze valency and collocability of the words effectiveness and efficiency was made on the material of 700 titles and abstracts of technical research articles on petroleum science. According to dictionary definitions, these notions possess both common and different features. However, for the purposes of teaching English for specific purposes and technical translation, they need more specification. The results of a comparative analysis showed that, firstly, effectiveness appeared to be $40 \%$ more frequently used (Tb. 3). Secondly, despite some similarities in syntactic valency, there were clear distinctions, related to the frequency of their occurrence in those syntactic positions. Typical syntactic structures for effectiveness were $\mathrm{V}+\mathrm{N}(\mathrm{E})+\mathrm{of}+\mathrm{N}$ : assess the effectiveness of the proposed method; $\mathrm{N}(\mathrm{E})+\mathrm{o}+\mathrm{N}$ : the effectiveness of the designated mud pulse generator; and less frequently $\mathrm{V}+\mathrm{A}+\mathrm{N}(\mathrm{E})$ : foam effectiveness. Whereas, efficiency normally occurred in $\mathrm{V}+\mathrm{A}+\mathrm{N}(\mathrm{E})$ : improve production efficiency; $\mathrm{A}+\mathrm{N}(\mathrm{E})$ : injection efficiency, and less frequently in $\mathrm{V}+\mathrm{N}(\mathrm{E})+\mathrm{of}+\mathrm{N}$ : increase 
the efficiency of calcium sulfate scale prevention. Thirdly, effectiveness tended to combine with method-related notions; while efficiency — with lexical units denoting processes, actualizing its technical meaning. Finally, both effectiveness and efficiency were occasionally used as attributes.

(C) Филясова ЮА.

Дата поступления: 18.08.2018

Дата приема в печать: 26.01.2019

\section{REFERENCES}

1. Ginzburg, R.S., Khidekel, S.S., Knyazeva, G.Y., \& Sankin, A.A. (1979). A course in modern English lexicology. Moscow: Higher School. (In Russ.).

2. Filipec, J. (1994). Lexicology and lexicography: Development and state of the research. In: Prague school of structural and functional linguistics, Ph.A. Luelsdorff (Ed). Amsterdam: John Benjamins B.V. pp. 163-185.

3. Yudina, N.V. (2006). On some new phenomena in lexeme collocating in the modern Russian language (based on attributive-substantive complexes). Izvestia: Herzen University Journal of Humanities and Science, 16, 75-84. (In Russ.).

4. Katznelson, S.D. (1987). To the notion of types of valency. Voprosy Jazykoznanija (Topics in the study of language), 3, 20-32. (In Russ.).

5. Kobrina, N.A. (2007). Is there any regular correspondence between the lexical meaning of a verb and its grammatical paradigm? Issues of Cognitive Linguistics, 4, 40-43. (In Russ.)

6. Paducheva, E.V. (2001). About the structure of the semantic field "perception". Topics in the Study of Language, 4, 23-44. (In Russ.).

7. Kalinina, O.N. (2008). Unity of the notions valency, function and position. Izvestia: Herzen University Journal of Humanities and Science, 69, 111-114. (In Russ.).

8. Stowell, T.A. (1981). Origins of phrase structure [abstract of dissertation]. Massachusetts: Massachusetts Institute of Technology.

9. Chomsky, N. (1965). Aspects of the Theory of Syntax. Cambridge, Massachesetts: MIT Press.

10. Kobrina, N.A., Korneeva, E.A., Ossovskaya, M.I. \& Guseeva, K.A. (2004). Grammar of the English language: Morphology. Syntax: A coursebook. St. Petersburg: Union.

11. Ermilova, M.L. (1993). Collocability of phraseological units with words, Vestnik of Saint-Petersburg University, 4, 78-80. (In Russ.)

12. Mitrofanova, I.I. \& Chernova, N.V. (2013). Work on lexical combinability based on political texts in foreign audience. RUDN Journal of Russian and Foreign Languages Research and Teaching, 3, 39-43. (In Russ.)

13. Novikov, L.A. (2011). The reflection of stylistic synonymy in the context of literary works, RUDN Journal of Language Studies, Semiotics and Semantics, 2, 49-53. (In Russ.)

14. Arnold, I.V. (2012). Lexicology of modern English language: A coursebook. Moscow: FLINTA.

15. Filyasova, Y.A. (2015). Continuous and end-of-module assessment system modelling for secondlanguage communicative competence evaluation. RUDN Journal of Russian and Foreign Languages Research and Teaching, 4, 220-223. (In Russ.)

16. Arutyunova, N.D. (1976). Sentence and its meaning: Logical and semantic issues. Moscow: Nauka. (In Russ.)

\section{Journals / Журналы}

17. Journal of Petroleum Geology. URL: https://onlinelibrary.wiley.com/journal/17475457 (accessed: 5.07.18).

18. Petroleum Geoscience. URL: http://pg.lyellcollection.org/ (accessed: 8.07.18). 
19. Journal of Unconventional Oil and Gas Resources. URL: https://www.journals.elsevier.com/ journal-of-unconventional-oil-and-gas-resources (accessed: 10.07.18).

20. Journal of Petroleum Science and Engineering. URL: https://www.journals.elsevier.com/ journal-of-petroleum-science-and-engineering (accessed: 12.07.18).

21. Marine and Petroleum Geology. URL: https://www.journals.elsevier.com/marine-andpetroleumgeology (accessed: 15.07.18).

22. Petroleum Exploration and Development. URL: https://www.journals.elsevier.com/petroleumexploration-and-development (accessed: 1.07.18).

23. Petroleum Science. URL: https://www.springer.com/earth+sciences+and+geography/mineralogy+ $\% 26+$ sedimentology/journal/12182 (accessed: 7.07.18).

\title{
Dictionaries / Словари
}

24. Macmillan Dictionary. URL: https://www.macmillandictionary.com/ (accessed: 7.07.18).

25. Cambridge Dictionary. URL: https://dictionary.cambridge.org/ (accessed: 7.07.18).

26. Merriam-Webster Dictionary. URL: https://www.merriam-webster.com/ (accessed: 7.07.18).

27. Oxford Dictionary. URL: https://en.oxforddictionaries.com/ (accessed: 7.07.18).

УДК: 81'276.6:62

DOI: $10.22363 / 2313-2299-2019-10-1-187-196$

\section{EFFECTIVENESS VS. EFFICIENCY: АНАЛИЗ ВАЛЕНТНОСТИ И СОЧЕТАЕМОСТИ В ТЕХНИЧЕСКОМ КОНТЕКСТЕ}

\author{
Ю.А. Филясова \\ Санкт-Петербургский горный университет \\ 21-я линия, д. 2, Васильевский остров, Санкт-Петербург, Россия, 199106
}

\begin{abstract}
В статье представлены результаты лексико-синтаксического анализа валентности и сочетаемости английских слов, относящихся к одной семантической группе: effectiveness и efficiency. Целью исследования было изучить способность данных слов вступать в лексические и синтаксические связи, учитывая некоторую разницу в их лексических значениях, представленных в словарных дефинициях. В задачи исследования входило определение семантических различий и анализ частей речи слов в левом и правом контекстах. Материалом анализа стали 700 заголовков и аннотаций статей из семи международных журналов по геологоразведочной и нефтегазовой тематике. Объем материала составил 177,444 слов. Методы исследования включали сплошную выборку, классификацию, анализ дефиниций, синтаксических связей и лексических значений релевантных слов. В результате исследования было выявлено, что частота употребления слова effectiveness на $40 \%$ выше, чем слова efficiency. Effectiveness и efficiency имеют сходства на уровне синтаксической валентности: они встречаются в одинаковых синтаксических структурах, однако, с разной частотностью. Разница наиболее заметна в таких синтаксических последовательностях как $\mathrm{N}(\mathrm{E})+\mathrm{of}+\mathrm{N}$, которая характерна для effectiveness, и $\mathrm{V}+\mathrm{A}+\mathrm{N}(\mathrm{E})$ - для efficiency. Типичным примером для effectiveness может служить the effectiveness of the proposed method; для efficiency - improve production efficiency. В отношении лексической сочетаемости необходимо отметить, что effectiveness чаще употребляется с лексическими единицами, обозначающими методы, в то время как efficiency процессы. Полученные данные соотносятся с информацией, полученной из словарных дефиниций: effectiveness имеет более широкое семантическое поле (что объясняет более высокую частоту встречаемости) и ориентировано на результат, в то время как efficiency в большей степени указывает на процесс и имеет дополнительное техническое значение. Результаты анализа могут быть исполь-
\end{abstract}


зованы в практике преподавания английского языка как иностранного для технических направлений подготовки студентов и перевода технических текстов.

Key words: валентность, сочетаемость, частотность слов, синтаксическая структура, английский язык

\section{БИБЛИОГРАФИЧЕСКИЙ СПИСОК}

1. Гинзбург Р.З., Хидекель С.С., Князева Г.Ю., Санкин А.А. Курс по современной английской лексикологии. М.: Высшая школа, 1979.

2. Филипек Дж. Лексикология и лексикография: Развитие и современное состояние исследований. В: Пражская школа структурной и функциональной лингвистики / Под ред. Ф.А. Луельсдорфа. Амстердам: Джон Бенжаминс Б.В., 1994. С. 163-185.

3. Юдина Н.В. О некоторых новых явлениях в сочетаемости лексем современного русского языка (на материале атрибутивно-субстантивных комплексов) // Известия Российского государственного педагогического университета им. А.И. Герцена. 2006. nо 16. С. 75-84.

4. Кацнельсон С.Д. К понятию типов валентности // Вопросы языкознания. 1987. nо. C. $20-32$.

5. Кобрина Н.А. Вопрос о соотношении между лексическим значением глагола и полнотой его парадигм // Вопросы когнитивной лингвистики. 2007. № 4. С. 40-43.

6. Падучева E.B. К структуре семантического поля «восприятие» // Вопросы языкознания. 2001. no 4. C. $23-44$.

7. Калинина О.Н. Единство понятий валентности, функции и позиции // Известия Российского государственного педагогического университета им. А.И. Герцена. 2008. nо 69. C. $111-114$.

8. Стоуэлл Т.А. Истоки структуры фразы: дисс. ... д.ф.н. Массачусетс: Массачусетский технологический институт (МТИ), 1981.

9. Хомский Н. Аспекты теории синтаксиса. Массачусетс: МТИ Пресс, 1965.

10. Кобрина Н.А., Корнеева Е.А., Оссовская М.И., Гузеева К.А. Грамматика английского языка: Морфология. Синтаксис: учеб. пособие. СПб.: Союз, 2004.

11. Ермилова М.Л. Сочетаемость фразеологических единиц со словами // Вестник СанктПетербургского государственного университета. 1993. nо 4. С. 78-80.

12. Митрофанова И.И., Чернова Н.В. Лексическая сочетаемость в общественно-политических текстах и работа над ней в иностранной аудитории // Вестник Российского университета дружбы народов. Серия: Русский и иностранные языки и методика их преподавания. 2013. no 3. C. $39-43$.

13. Новиков А.Л. Отражение стилистической синонимии в контексте художественных произведений // Вестник Российского университета дружбы народов. Серия: Теория языка. Семиотика. Семантика. 2011. по 2. С. 49-53.

14. Арнольд И.В. Лексикология современного английского языка: учеб. пособие. М.: ФЛИНТА: Наука, 2012.

15. Филясова Ю.А. Моделирование системы непрерывного и тематического контроля уровня развития иноязычной коммуникативной компетенции // Вестник Российского университета дружбы народов. Серия: Русский и иностранный языки и методика их преподавания. 2015. no 4. С. $210-223$.

16. Арутюнова Н.Д. Предложение и его смысл: Логико-семантические проблемы. М.: Наука, 1976.

\section{Для цитирования:}

Филясова Ю.А. Effectiveness vs. efficiency: анализ валентности и сочетаемости в техническом контексте // Вестник Российского университета дружбы народов. Серия: Теория языка. Семиотика. Семантика. 2019. Т. 10. nо 1. С. 187-196. doi: 10.22363/2313-2299-2019-10-1-187-196. 


\section{For citation:}

Filyasova Yu.A. (2019) Effectiveness vs. efficiency: an analysis of valency and collocability in a technical context. RUDN Journal of Language Studies, Semiotics and Semantics, 10 (1), 187-196. doi: 10.22363/2313-2299-2019-10-1-187-196.

\section{Сведения об авторе:}

Филясова Юлия Анатольевна, кандидат филологических наук, доцент кафедры иностранных языков Санкт-Петербургского горного университета (Россия); научные интересы: лингвистика, фонетика, деловой английский, технический перевод, медиадискурс, преподавание английского языка; e-mail: phill.yield@gmail.com

\section{Information about the author:}

Filyasova Yulia Anatolyevna, Candidate of Philology, Associate Professor, Department of Foreign Languages, Saint-Petersburg Mining University (Russia); scientific interests: linguistics, phonetics, business English, technical translation, media discourse, English language teaching; e-mail: phill.yield@gmail.com 